\title{
Adriana Kapała
}

[Warszawa]

(iD https://orcid.org/000o-0003-1544-9145

\section{Mariusz Bieciuk}

[Białystok]

(D) https://orcid.org/00oo-0002-9569-437X

Sprawozdanie z projektu dokumentacyjnego

„Na tatarskim szlaku - dokumentacja

i popularyzacja tradycji i kultury Tatarów

w województwie podlaskim"

DOI: $10.26774 / \mathrm{wrhm} .279$ 
Dzięki wsparciu Ministerstwa Kultury i Dziedzictwa Narodowego w programie „Kultura ludowa i tradycyjna” od 24 czerwca do 5 lipca 2019 r. zespół dokumentalistów Fundacji Ośrodka K A RT A i Białostockiego Ośrodka Kultury/Centrum im. Ludwika Zamenhofa realizował projekt nagrywania relacji biograficznych polskich Tatarów w województwie podlaskim. Zespół składał się z czwórki dokumentalistów: Dominika Czapigo, Adriany Kapały (koordynatorki projektu) i Joanny Łuby - z Fundacji Ośrodka KARTA oraz Mariusza Bieciuka z Białostockiego Ośrodka Kultury/Centrum im. Ludwika Zamenhofa. Partnerem projektu był Muzułmański Związek Religijny w Rzeczypospolitej Polskiej.

W trakcie trwającego dwa tygodnie wyjazdu dokumentacyjnego nagraliśmy 32 relacje biograficzne z polskimi Tatarami (w projekcie zakładaliśmy 20). Dodatkowo zeskanowaliśmy ponad 100 fotografii (najstarsza została wykonana w drugiej połowie xIx w. w Petersburgu) i artefakty (np. kartę tytułową Koranu z 1901 r., żeton tożsamości - potocznie: nieśmiertelnik, wydany podczas mobilizacji tuż przed wybuchem II wojny światowej z symbolem wyznania mahometańskiego). Dokumentacja odbywała się na terenie województwa podlaskiego w następujących miastach i wsiach: Białystok, Bohoniki, Kruszyniany, Sokółka i Suchowola.

Mimo bogatej i ciągle rozwijającej się literatury przedmiotu ${ }^{1}$ oraz wielowiekowego osadzenia mniejszości tatarskiej na ziemiach polskich ${ }^{2}$ wciąż jest to stosunkowo mało zbadana grupa. Do tej pory prace dokumentacyjne związane z polskimi Tatarami oparte na metodzie oral history nie były prowadzone ${ }^{3}$. Ich tradycje i historia są unikatowym zapisem doświadczenia mniejszościowej grupy etnicznej i wyznaniowej na terenie Polski.

$1 \quad$ Zob. np.: K. Radłowska, Tatarzy polscy. Ciągłość i zmiana, Białystok 2017; P. Borawski, A. Dubiński, Tatarzy polscy. Dzieje, obrzędy, legendy, tradycje, Warszawa 1987; A. Miśkiewicz, Tatarzy polscy 1918-1939. Życie społeczno-kulturalne i religijne, Warszawa 1990.

2 O początkach osadnictwa tatarskiego możemy mówić od drugiej połowy xıv w., kiedy pierwsi osadnicy dotarli na ziemie ówczesnego Wielkiego Księstwa Litewskiego z obszaru Złotej Ordy. Przez kilka stuleci osadnictwo tatarskie miało charakter wojskowy, a mniejszość ta zamieszkiwała nadane przez władców ziemie - głównie na terenach obecnej Litwy i Białorusi. Osadnictwo w granicach obecnej Rzeczypospolitej Polskiej rozpoczęło się pod koniec xVII w., kiedy król Jan II I Sobieski w zamian za zaległy żołd przyznał Tatarom ziemię w Studziance, Nietupach, Łużanach, Drahlach, Malawiczach, Kruszynianach i Bohonikach. Z czasem Tatarzy zatracili swój rodzimy język i zaczęli posługiwać się językiem polskim. Dzięki zapewnionej swobodzie wyznawania islamu i możliwości kultywowania własnych obyczajów wielu z nich pozostało wiernymi tradycjom przodków. Tatarzy cieszyli się swobodą religijną.

3 Karolina Radłowska do swojej książki Tatarzy polscy. Ciągłość i zmiana posłużyła się metodą wywiadu - przeprowadziła ich łącznie 40, były to jednak wywiady nastawione na badanie aspektu etnicznego. 
Założeniem projektu było udokumentowanie historii i kultury zapisanej w pamięci osób utożsamiających z się z grupą polskich Tatarów. W kręgu naszych zainteresowań w toku prac dokumentacyjnych znalazły się m.in. elementy tradycyjnej kultury wraz z ich przekształceniami, islam i przestrzeganie jego nakazów (także elementy przejmowane z kultury chrześcijańskiej), poczucie tożsamości i stopień przywiązania do kultury tatarskiej. W trakcie wywiadów zarejestrowaliśmy również zwyczaje związane z uroczystościami rodzinnymi (np. azanem, ślubem, pogrzebem) i świętami (np. Kurban Bajram).

Wywiady zostały przeprowadzone w nurcie biograficzno-narracyjnym - każdy wywiad został podzielony na część swobodą oraz część z pytaniami. W części swobodnej rozmówcy sami opowiadali o swoim życiu, począwszy od najwcześniejszych wspomnień do czasów współczesnych. W drugiej części wywiadu posłużyliśmy się przygotowanym wcześniej zestawem pytań (oczywiście nie był to zestaw zamknięty):

1. Jakie jest Pani/Pana poczucie tożsamości?

2. Jaki jest Pani/Pana stosunek do religii?

3. Jak wygląda zachowywanie nakazów religijnych (wyznanie wiary, modlitwa, jałmużna, post, pielgrzymka do Mekki)?

4. Jakie są dla Pani/Pana ważne miejsca związane z własną kulturą, tożsamością?

5. Jak obchodzi Pani/Pan święta? Jakie pamięta Pani/Pan zwyczaje z dzieciństwa, których już się nie kultywuje?

6. Jaki stosunek mają do Was chrześcijanie? Czy spotkał(a) się Pani/Pan z przejawami dyskryminacji?

7. Jakie są tradycje, zwyczaje charakterystyczne dla Tatarów w Polsce?

8. Jak wygląda nauka religijna?

9. Jak zmieniło się postrzeganie Tatarów na przestrzeni lat (wpływ zamachów na World Trade Center w 2001 r.)?

10. Jak wyglądają relacje $\mathrm{z}$ innymi muzułmanami (przyjezdnymi, nie-Tatara$\mathrm{mi})$ ?

Wśród nagranych osób znaleźli się przedstawiciele różnych pokoleń: najstarsze nagrane osoby urodziły się jeszcze w latach 30., najmłodsze zaś w latach 80. xx w. Taki dobór świadków wynikał z potrzeby ujęcia przeobrażeń społeczności na poziomie następujących po sobie pokoleń oraz był efektem dość hermetycznego charakteru środowiska tatarskiego, w którym duże znaczenie mają koligacje i powiązania rodzinne (tym samym świadkowie byli często wskazywani lub polecani przez osoby cieszące się w środowisku tatarskim autorytetem). Większość świadków została nagrana w Białymstoku (13 relacji) i kolejno w Sokółce (11 relacji), Kruszynianach (4 relacje), Bohonikach (3 relacje) i Suchowoli (1 relacja).

Zebrany materiał pozwala na wyróżnienie kilku obszarów tematycznych, które mogą być eksplorowane przez badaczy zainteresowanych tatarszczyzną. 
Pierwszym i pojawiającym w każdym z przeprowadzonych wywiadów zagadnieniem jest bycie Tatarem i religia jako spoiwo zarówno poczucia tożsamości, jak i przynależności do grupy. Te dwa elementy nie tylko budują tożsamość rozmówców, ale są osią całej części swobodnej narracji, czyli opowieści o życiu. Islam jest kultywowany przez wszystkich nagranych w projekcie świadków. Zauważalne jest, że wśród osób starszego pokolenia (urodzonych w latach 30. i 40. xx w.) nauka religii często nie miała żadnej nadanej formy i zajmowali się nią rodzice. Dopiero w wypadku osób urodzonych w kolejnych dziesięcioleciach pojawiła się możliwość nauki religii w formie zorganizowanej: w domach, nauczanej przez imama, lub później - w salkach modlitewnych dostosowywanych do nauki religii. Wśród starszego pokolenia nagranych rozmówców przywiązanie do kwestii religijnych wynika w dużej mierze z tradycji rodzinnych i nie zawsze ma charakter pogłębionej refleksji. Ze względu na warunki życia po wojnie, a także odcięcie polskich Tatarów od innych ośrodków związanych z islamem, utrzymanie własnej religii i tradycji było dużym wyzwaniem. Pierwsze pogłębione kontakty polskich muzułmanów ze światem muzułmańskim (wąsko: arabskim) przypadły dopiero na lata 70. i 80. xx w., kiedy w Polsce zaczęli pojawiać się studenci z krajów arabskich. Świadkowie, którzy pamiętali organizowane przez nich zajęcia religijne, często jednak podkreślali, że przybywający studenci nie rozumieli specyfiki „polskiego islamu” i nie byli w stanie zaakceptować wielu naleciałości przejętych z kultury chrześcijańskiej. Z kolei polscy Tatarzy nie godzili się na narzucanie restrykcyjnych zasad islamu, niemających nic wspólnego z przyjętą przez siebie obyczajowością i tradycjami.

W wypadku zagadnień religijnych polscy Tatarzy bardzo często odwoływali się do warunków życia w Polsce oraz podkreślali związane z tym trudności. Przy czym warto zaznaczyć, że zaledwie jedna osoba (spośród 32 nagranych) jasno mówiła o przestrzeganiu wszystkich zasad religijnych i dostosowaniu swojego stylu życia w pełni do wymagań islamu ${ }^{4}$. W części rozmów ważne miejsce zajmowały filary islamu. Większość rozmówców odwoływała się do trudności, jakie niesie z sobą przestrzeganie niektórych nakazów religijnych: w odniesieniu do postu (ramadanu), który jest świętem ruchomym, problemem jest przestrzeganie zakazu spożywania posiłków i picia wody od świtu do zmierzchu w miesiącach letnich. Niektórzy rozmówcy wskazywali, że nakazów przestrzegają zgodnie w własnymi możliwościami zdrowotnymi oraz życiowymi. Osoby pracujące na przykład nie zawsze mają możliwość spełnienia wymogu pięciokrotnej modlitwy w ciągu dnia i odmówienia jej w godzinach pracy. sygn. FOK_0133_0001, Relacja Dagmary Sulkiewicz, 26 vi 2019 r. (sporządziła A. Kapała). 
Na uwagę zasługuje temat pielgrzymki do Mekki (hadżdż), gdyż dzięki finansowemu wsparciu Królestwa Arabii Saudyjskiej od kilku lat członkowie społeczności tatarskiej mogą uczestniczyć w takiej pielgrzymce. Większość osób ze starszego pokolenia jednak nie brała w pielgrzymce udziału ze względów zdrowotnych. Pielgrzymowali głównie świadkowie urodzeni w latach 60. xx w. i później, którzy byli w stanie podjąć ów kilkudniowy trud.

W każdej rozmowie pojawił się temat związany ze zwyczajami i z obrzędami religijnymi. Trzeba przy tym podkreślić, że religia jest tutaj wspólnotą pewnych doświadczeń, składnikiem „bycia Tatarem” - niezależnym często od indywidualnego przeżywania religijności czy potrzeb duchowych poszczególnych osób. Ważne miejsce w nagranych relacjach zajmują opowieści związane z obrzędami religijnymi - począwszy od uroczystości rodzinnych (azan, ślub, pogrzeb) poprzez święta obchodzone w szerszym gronie społeczności tatarskiej. Do najważniejszych świąt islamu zaliczają się Kurban Bajram (w czasie którego składana jest ofiara ze zwierzęcia ${ }^{5}$ ) oraz Ramadan Bajram, który kończy ramadan. Warto zaznaczyć, że ramadan, czyli miesiąc postu, w czasie którego muzułmanie wstrzymują się z posiłkami od wschodu do zachodu słońca, odgrywa ważną rolę w życiu religijnym społeczności. Wielu rozmówców podkreślało rolę tego miesiąca w życiu religijnym oraz wspólnotowość doświadczenia postu, jako jednoczącego i duchowo oczyszczającego.

Tatarzy, których relacje zostały pozyskane w czasie realizacji projektu, określali się najczęściej podwójnym mianem: Tatarów i Polaków. Oczywiście uzyskane informacje stanowią podstawę analizy badań nad poczuciem tożsamości i nad skutkami „podwójnej tożsamości”. Osoby zajmujące się taką tematyką na pewno znajdą w tej kolekcji wiele cennych zapisów. Bycie Tatarem było jednocześnie silnie związane z byciem muzułmaninem. Łączy się to z coraz częstszymi małżeństwami mieszanymi ${ }^{6}$ i odejściem od tradycyjnych zawodów ${ }^{7}$, co powoduje, że to właśnie religia jest głównym wyróżnikiem dla tej mniejszości.

Wymienione wyżej obszary/tematy, jakie pojawiły się w relacjach, to oczywiście jedynie przykłady, mające na celu zobrazowanie bogactwa kolekcji. Osoby zajmujące się tatarszczyzną (zawodowo, a także hobbistycznie) mogą korzystać z relacji dotyczących również innych, nieopisanych tutaj szczegółowo obszarów (przykładowo: osadnictwo powojenne Tatarów na tzw. Ziemiach Odzyskanych; kontakty z Tatarami krymskimi, którzy osiedlili się w Polsce).

5 Wokół składania ofiar toczy się zresztą od dłuższego czasu dyskusja dotycząca obecności w Polsce uboju rytualnego.

6 Nie ma przy tym reguły dotyczącej wychowywania dzieci w jednej z religii przez takie rodziny. Jest to zawsze indywidualna decyzja, chociaż - co często podkreślano w wywiadach - kulturowo łatwiejsze jest wychowanie dzieci w religii katolickiej.

7 Do takich tradycyjnych zawodów wykonywanych przez Tatarów jeszcze w dwudziestoleciu międzywojennym można zaliczyć np. garbarstwo i ogrodnictwo. 
Cała kolekcja nagrań (13 relacji wideo oraz 19 relacji audio) została opracowana archiwalnie. Stworzono kwestionariusze nagrań z minutnikiem i opisem hasłowym według jednego zestandaryzowanego wzoru. Opracowano biogramy wszystkich rozmówców. Opisano relacje, stosując rozbudowany indeks haseł dotyczących: wydarzeń historycznych, osób, nazw geograficznych i własnych. Dodatkowo poddano transkrypcji 20 relacji. Z nagrań wybrano 85 najciekawszych fragmentów dźwiękowych, które zostały wraz z opracowaniami udostępnione na portalu Otwarty System Archiwizacji.

Zebrane w czasie wyjazdu dokumentacyjnego wywiady zostały zabezpieczone w Fundacji Ośrodka KARTA oraz w Białostockim Ośrodku Kultury/Centrum im. Ludwika Zamenhofa. Wywiady w postaci opracowań i fragmentu są dostępne na stronach Otwartego Systemu Archiwizacji ${ }^{9}$ i Mediateki CLz ${ }^{10}$. Całych wywiadów można posłuchać po wcześniejszym kontakcie z jedną z wymienionych instytucji.

Jednym z efektów projektu jest wystawa otwarta w sierpniu 2020 r. w Białostockim Ośrodku Kultury/Centrum im. Ludwika Zamenhofa. Ekspozycja, która powstała na podstawie materiałów zebranych w trakcie wyjazdu dokumentacyjnego, jest próbą uchwycenia specyfiki kulturowej mniejszości tatarskiej w Polsce. Koncentruje się na historii społeczności i losach jej członków w xx w., m.in. poprzez szukanie odpowiedzi na pytanie o zewnętrzne przyczyny, które doprowadziły do osiedlenia się i pozostania na Podlasiu bohaterów prezentowanych nagrań i fotografii.

Wystawa została podzielona na cztery części zgodnie z najważniejszymi wątkami pojawiającymi się w narracjach, z których każdy składa się ze stałych elementów: wprowadzającego tekstu badaczki mniejszości tatarskiej dr Karoliny Radłowskiej, wybranych fragmentów wywiadów oraz archiwalnych fotografii:

1. Korzenie - większość rozmówców pochodzi z Kresów Wschodnich lub stamtąd pochodzą ich rodzice, część od kilku pokoleń zamieszkuje też na Podlasiu. Dla nich wszystkich pochodzenie oraz związki z rodziną i często utraconą ojcowizną są niezwykle ważne i stanowią istotny element tożsamości grupy, akcentowany w większości relacji.

Dla podkreślenia pochodzenia i migracji społeczności tatarskiej dodano do tego rozdziału dwa kluczowe elementy: mapę, pokazującą migracje Tatarów po II wojnie światowej - w latach 1945-1960 z Kresów Wschodnich na tzw. Ziemie Odzyskane, później (od lat 6o. xx w.) na Podlasie, z zaznaczonymi miejscowościami, w których mieszkali uczestnicy projektu; a także album z biogramami świadków. Połączenie tych elementów pozwala prześledzić losy poszczególnych osób na tle

8 Zob. osa.archiwa.org (dostęp: 19 II 2021 r.).

9 Zob. https://osa.archiwa.org/zbiory/PL_1001_FOK_0133 (dostęp: 19 II 2021 r.).

10 Zob. http://www.mediateka.centrumzamenhofa.pl/videos/projects/8599/ (dostęp: 19 II 2021 r.). 
migracji całej społeczności tatarskiej, a w szerszej perspektywie - pokazuje jeden ze skutków przesunięcia na zachód granic Polski po II wojnie światowej.

2. Etniczność - kolejny istotny element tożsamości polskich Tatarów. Z jednej strony charakteryzuje się ona silnym związkiem z polskim narodem, z drugiej - widoczna jest ich odmienność religijna, charakterystyczne tradycje i obrzędy oraz silne więzi etniczne łączące grupę z innymi ludami turkijskimi. Świadkowie często określali się jako i Polacy, i Tatarzy.

3. Religia - polscy Tatarzy to wyznawcy islamu obrządku sunnickiego. Stanowią oni autochtoniczną i najstarszą z grup muzułmańskich żyjących w naszym kraju. Na skutek wielowiekowego odseparowania od ważnych centrów muzułmańskich oraz w wyniku sąsiedztwa z ludnością chrześcijańską „islam tatarski” pod względem niektórych praktyk religijnych oraz obrzędów odbiega od wzorów bliskowschodnich.

4. Codzienność - jeszcze w okresie II Rzeczypospolitej największą grupę wśród Tatarów stanowili rolnicy, garbarze, urzędnicy, reprezentanci zawodów wolnych, wyrobnicy, ogrodnicy, duchowni, rymarze, szewcy, krawcy, kuśnierze i niżsi funkcjonariusze państwowi. Wśród tradycyjnych zawodów tatarskich należy wymienić także furmaństwo i hodowlę koni. W wyniku II wojny światowej grupa niemal zupełnie pozbawiona została inteligencji. Procesy powojenne doprowadziły także do zmian w strukturze społecznej grupy, przyczyniając się do zaniku tradycyjnych profesji, takich jak garbarstwo czy ogrodnictwo. Dziś, w życiu codziennym społeczność tatarska niczym nie różni się od innych grup żyjących w Polsce ${ }^{11}$.

Całości ekspozycji dopełniają artefakty udostępnione przez świadków oraz przez Muzeum Podlaskie w Białymstoku: Koran z 1901 r. przywieziony z Niekraszuńc, żeton tożsamości z okresu II wojny światowej, karty repatriacyjne, tespih $^{12}$, ręcznie pisane Chamiły ${ }^{13}$, nuski ${ }^{14}$ i Daławar $^{15}$ oraz film Kurban Bajram

11 Opisy poszczególnych części zaczerpnięte są z tekstów do wystawy autorstwa dr Karoliny Radłowskiej.

12 Muzułmański sznur modlitewny składający się z 33 (lub 99) paciorków oraz kilku dodatkowych, pełniących funkcję ozdobną. Służy do systematycznego wymawiania 99 tzw. atrybutów (imion) Allaha.

13 W tradycji Tatarów polsko-litewskich to modlitewnik przeznaczony do osobistego, codziennego użytku, zawierający praktyczny opis rytuału muzułmańskiego, okolicznościowe formuły i inne teksty dewocyjne, tablice z kalendarzem muzułmańskim oraz teksty związane z magią (opis: Lucyna Lesisz, Muzeum Podlaskie w Białymstoku).

14 Amulet w postaci karteczki z wypisanym z chamaiłu tekstem arabskiej modlitewki, formuły lub figury magicznej o przeznaczeniu ochronnym lub leczniczym (opis: Lucyna Lesisz, Muzeum Podlaskie w Białymstoku).

15 Muzułmański zwój z modlitwami ochronnymi i zbawiennymi. Ma charakter osobisty i przeznaczony jest tylko dla muzułmanów. Daławary są umieszczane w różnych miejscach: w domach, warsztatach, zakładach pracy. Służą jako amulety ochronne w czasie podróży lub wypraw wojennych. Są też grzebane razem ze zmarłymi w trakcie pochówku (opis: Lucyna Lesisz, Muzeum Podlaskie w Białymstoku). 
z 1958 r. w reżyserii Roberta Stando. Ten krótki dokument, nagrany podczas obchodów święta Kurban Bajram w Bohonikach, porusza istotne aspekty kultury Tatarów. Wśród jego bohaterów jest wielu świadków, którzy udzielili wywiadów na potrzeby projektu.

Ostatnim, ale też najważniejszym aspektem wystawy, jest jej wymiar osobisty. Stworzenie ekspozycji w tak różnorodnej i bogatej formie było możliwe tylko dzięki współpracy z jej bohaterami. To ich relacje były punktem wyjścia do jej powstania i to one nadały jej ostateczny kształt. Nie będzie więc przesadne stwierdzenie, że wystawa ma charakter nieformalnej, mówionej autobiografii podlaskich Tatarów ${ }^{\mathbf{1 6}}$.

16 Kuratorzy wystawy: Anna Talarczyk, Mariusz Bieciuk, autorka tekstu: dr Karolina Radłowska, konsultacja merytoryczna: dr Barbara Miśkiewicz, projekt aranżacji: Magdalena Płońska. Wystawę można bezpłatnie wypożyczyć w Białostockim Ośrodku Kultury/Centrum im. Ludwika Zamenhofa. 